\title{
サブストラクチャ擬似動的実験による せん断破壊型鉄筋コンクリート柱の崩壊実験 \\ COLLAPSE TEST OF SHEAR-FAILING R/C COLUMNS BY SUBSTRUCTURE PSEUDO-DYNAMIC TEST METHOD
}

\author{
中村孝也*, 芳村 学**, 見波 進 ${ }^{*}$ \\ Takaya NAKAMURA, Manabu YOSHIMURA and Susumu MINAMI
}

\begin{abstract}
Substructure pseudo-dynamic tests were conducted to simulate story collapse of old three-story R/C buildings. The buildings were idealized to consist of a single column line and rigid beam. The first-story column that was designed to fail in shear was tested by the substructure pseudo-dynamic method where the second- and third-story columns designed enough strong were assumed elastic. An imaginary mass was determined in such that the first mode period and Seismic Capacity Index, Is, might result in 0.15 second and 0.49 , respectively. Three earthquake records were used as input motions. Responses of the buildings, mostly those in the post-peak regions including collapse were studied.
\end{abstract}

Keywords: Reinforced concrete, Substructure pseudo-dynamic test, Shear failure, Collapse, Rigid beam 鉄筋コンクリート, サブストラクチャ擬似動的実験, せん断破壊, 崩壊, 剛梁

\section{1. はじめに}

既存の古い $\mathrm{RC}$ 建物の耐震性を精度良く評価するためには，その 中に存在することが多い脆弱なせん断破壊型柱の軸力保持能力䩚失 （崩壊）性状を把握することが重要である。これに関しては過去に いくつかの静的実験によって検討がなされているたとえば1) 3)。しかし 地震時の柱の崩壊性状を把握するためには載荷履歷があらかじめ決 まっている静的実験のみでは不十分で，動的な応答性状を把握する 必要がある。せん断破壊型柱の動的な崩壊性状については，過去に 振動台実験によって検討した例がいくつかあるたとえば 4) の)。しかし， 実験が大がかりなものになる等の理由により，数多くの実験を行う ことは困難である。一方，より簡易に動的応答を調べる手法として 擬似動的実験がある。しかし，せん断破壊型柱の擬似動的実験は過 去に少数行われているものの》，崩壊まで加力した例はない。

そこで本研究では，旧基準により設計されたせん断破壊型 RC 柱 を崩壊まで加力する擬似動的実験を行い，柱の動的崩壊性状を検討 する。実験は低層建物の応答性状を把握する意図から，3 層建物の 最下層を実験部分とするサブストラクチャ法により行う。加力方向 は建物のけた行方向とし，その方向は脆性的な柱のみからなる場合 を想定する（注 1）。ここで，実建物では張り間方向に壁が取り付く 場合が多いため，直交壁付き柱も実験対象とする。旧基準建物の耐 震性を評価する場合，ある構造耐震指標（Is 值） ${ }^{8)}$ を持った建物がど の程度の地震動レベルで崩壊するのかを調べることは非常に重要で あるため, 本研究ではその点について 3 種類の地震動を用いて検討

する。また，筆者らが過去に行った載荷履歴が決められている静的 実験 ${ }^{3)}$ と，そうではない擬似動的実験では崩壊性状に相違があるの か否かについても検討する。さらに, 建物崩壊を検討する手段とし て地震応答解析があるが，仮定した復元力特性を用いざるを得ない ため地震時に崩壊に至るまでの挙動を忠実に再現できるかについて の確証がないのが現状であることから，本実験結果を復元力特性に 適用した解析を行い，実験との適合性を検証する。

\section{2. 実験概要}

\section{1 対象建物}

旧基準 3 層 RC 建物を対象とし，各層は図 1 に示す柱から構成さ れていると仮定した。実験モデルは，剛梁を仮定して図 2 に示すせ ん断型モデルとし， 1 層を実験， 2，3 層を弾性解析によって処理す るサブストラクチャ擬似動的実験を行った。

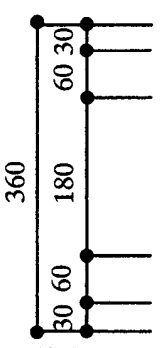

[単位: $\mathrm{cm}$ ]

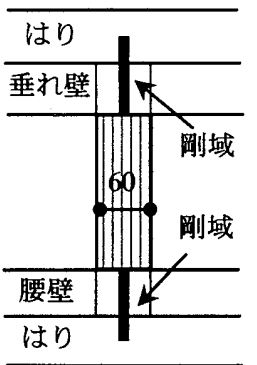

図 1 実建物のイメージ

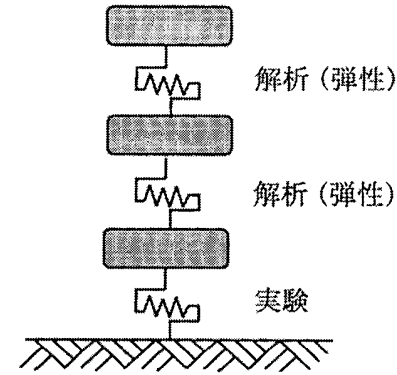

図 2 実験モデル
* 首都大学東京大学院都市環境科学研究科建築学専攻 助教・博士 (工学)

** 首都大学東京大学院都市環境科学研究科建築学専攻 教授・ 工博
Assistant Prof., Graduate School of Architecture and Building Engineering, Tokyo Metropolitan Univ., Dr. Eng.

Prof., Graduate School of Architecture and Building Engineering, Tokyo Metropolitan Univ., Dr. Eng. 
表 1 試験体諸元一管

\begin{tabular}{|c|c|c|c|c|c|c|c|c|c|c|c|c|c|}
\hline 試験体名 (1) & 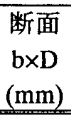 & $\begin{array}{c}\text { 内法 } \\
\text { 高さ } \\
h_{0}(\mathrm{~mm}) \\
\end{array}$ & $\mathrm{h}_{0} / \mathrm{D}$ & $\begin{array}{l}\text { 主筋比 } \\
\mathrm{p}_{\mathrm{g}}(\%)\end{array}$ & $\begin{array}{l}\text { せん断補強 } \\
\text { 筋比 } \mathrm{p}_{\mathrm{w}}(\%)\end{array}$ & 軸力比 2 & \begin{tabular}{|c|} 
入力 \\
地震動 \\
{$[2.6$ 節参照 $]$} \\
\end{tabular} & $\begin{array}{c}\text { 直交壁 } \\
\text { 断面 } \mathrm{t}_{\mathrm{w}} \times \mathrm{l}_{\mathrm{w}} \\
(\mathrm{mm}) \\
\end{array}$ & \begin{tabular}{|c|} 
せん断ひ \\
び割れ強 \\
度 $\mathrm{V}_{\mathrm{c}}{ }^{(3}(\mathrm{kN})$ \\
\end{tabular} & $\begin{array}{r}\text { トラス・アーチ } \\
\text { 機構によるせん } \\
\text { 断強度 } \mathrm{V}_{\mathrm{u}}^{\oplus}(\mathrm{kN}) \\
\end{array}$ & $\begin{array}{c}\text { 荒川式による } \\
\text { せん断強度 } \\
\mathrm{V}_{\mathrm{s}}^{(\mathfrak{G}}(\mathrm{kN}) \\
\end{array}$ & \begin{tabular}{|c} 
曲げ強度 \\
$\mathrm{V}_{\mathrm{f}}^{\circledR}$ \\
$(\mathrm{kN})$ \\
\end{tabular} & $\mid$\begin{tabular}{|} 
せん断 \\
余裕度
\end{tabular} \\
\hline C13-J & \multirow{6}{*}{$\begin{array}{c}300 \\
\times \\
300\end{array}$} & \multirow{6}{*}{900} & \multirow{6}{*}{3} & \multirow{6}{*}{$\begin{array}{c}1.69 \\
{[12-\mathrm{D} 13]}\end{array}$} & \multirow{6}{*}{$\begin{array}{c}0.11 \\
{[2-\mathrm{D} 6 @ 200]}\end{array}$} & \multirow{6}{*}{0.2} & JMA & \multirow{3}{*}{ なし } & \multirow{3}{*}{182} & \multirow{3}{*}{129} & \multirow{3}{*}{145} & \multirow{3}{*}{207} & \multirow{3}{*}{0.70} \\
\hline C13-T & & & & & & & TOH & & & & & & \\
\hline C13-H & & & & & & & $\mathrm{HCO}$ & & & & & & \\
\hline C13W60-J & & & & & & & JMA & \multirow{3}{*}{$\begin{array}{c}60 \times 250 \\
{[\times 2]}\end{array}$} & \multirow{3}{*}{ - } & \multirow{3}{*}{-} & \multirow{3}{*}{-} & \multirow{3}{*}{ - } & \multirow{3}{*}{ - } \\
\hline C13W60-T & & & & & & & $\mathrm{TOH}$ & & & & & & \\
\hline $\mathrm{C} 13 \mathrm{~W} 60-\mathrm{H}$ & & & & & & & $\mathrm{HCO}$ & & & & & & \\
\hline
\end{tabular}

(1)試験体名中の 13 は主筋が D13 であることを, W60 は厚さ $60 \mathrm{~mm}$ の直交壁が付いていることを示す。末尾のアルファベットは入力地震動の頭文字を示

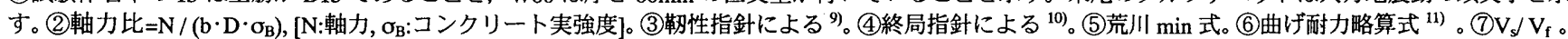

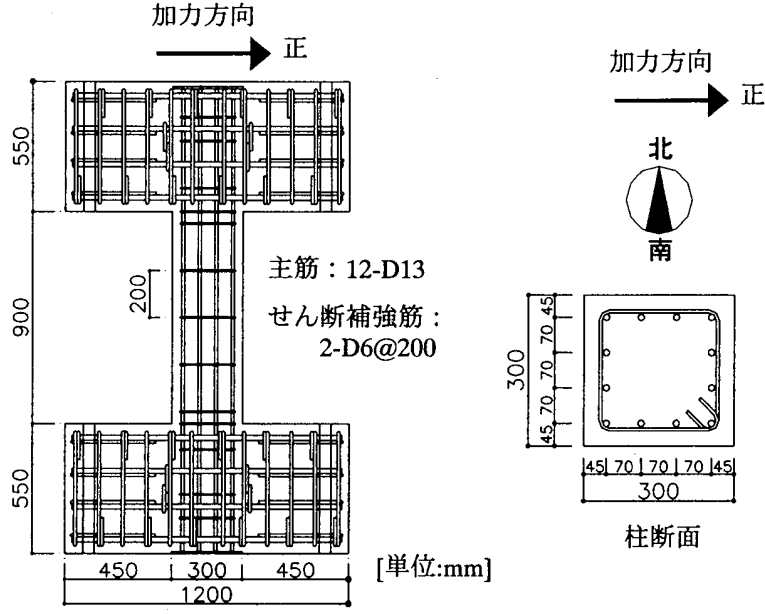

(a) C13-J, C13-T, C13-H
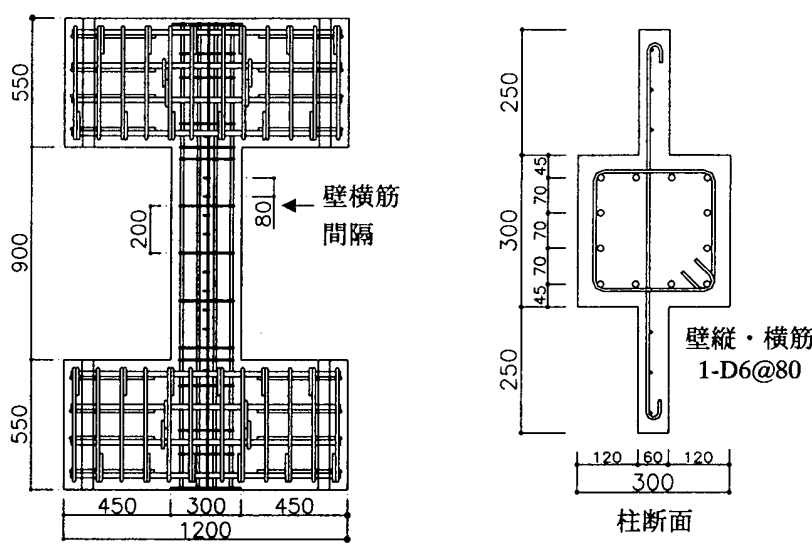

(b) C13w60-J, C13w60-T, C13w60-H

図 3 試倹体概要

\section{2 試検体}

試験体諸元を表 1 に, 試験体概要を図 3 に示す。試験体は実大建 物（図1）の長さのスケールを $1 / 2$ に縮小した両端固定形式の柱で, 壁が付かない柱（以後，壁なし柱と呼ぶ）および直交壁付き柱がそ れぞれ3体の計6体であり，すべてせん断破壊するように設計した。 なお，壁なし柱は文献 3)の試験体 C13，直交壁付き柱は同 C13W60 之同一の形状・配筋で，材料強度のみが異なる。

\section{共通事項}

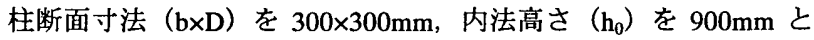
した $\left(\mathrm{h}_{0} / \mathrm{D}=3\right)$ 。柱の主筋比 $\mathrm{p}_{\mathrm{B}}$ は 1.69\%（D13 使用），せん断補強筋 比 $\mathrm{p}_{\mathrm{w}}$ は $0.11 \%$ （D6 使用）とした。鉄筋とコンクリートの材料特性 を表 2 に示す。材料のヤング係数は実建物と試験体で同じと考える。

表 2 材料特性

(a) 鉄筋

\begin{tabular}{|c|c|c|c|}
\hline 呼び名 & $\begin{array}{l}\text { 降伏強度 } \\
\left(\mathrm{N} / \mathrm{mm}^{2}\right)\end{array}$ & $\begin{array}{c}\text { 降伏歪 } \\
(\%)\end{array}$ & $\begin{array}{c}\text { ヤング係偻 } \\
\left(\mathrm{N} / \mathrm{mm}^{2}\right)\end{array}$ \\
\hline D13 & 371 & 0.201 & $1.85 \times 10^{5}$ \\
\hline D6 & 366 & 0.245 & $1.60 \times 10^{5}$ \\
\hline
\end{tabular}

軸力は全試験体共通で, 柱のみの断面積に対する軸力比が 0.2 とな る一定軸力とした。なお,この軸力は, 2.3 節で後述する実大モデル の仮想重量から求まる軸力とは異なる。

実験パラメータ

実験パラメータは, 入力地震動および直交壁の有無とした。入力 地震動については 2.6 節に示す。直交壁は, 壁厚 $\left(\mathrm{t}_{\mathrm{w}}\right) \times$ 壁長さ $\left(1_{w}\right)=60 \times 250 \mathrm{~mm}$ の壁を柱の南北面に取り付けた。

\section{3 実大モデルの初期䯈性, 重量, 1 次固有周期}

本節では，実験で設定した実大モデルの諸元を示す。

初期剛性は,壁なし柱試験体の初期剛性を既往の式 ${ }^{11} に よ り$ 求め, 相似則により 2 倍にすることにより決定した。建物高さ方向の剛性 分布は, 低層建物では上部 3 層程度は柱を細くしないのが一般的で あることから，3 首とも同一の剛性とした。各層初期剛性は $360 \mathrm{kN} / \mathrm{mm}$ となった。

仮想重量は各層同一と仮定して, 1 次固有周期が $0.15 \mathrm{~s}$ となるよう に, 前述の初期剛性を用いて算出した。各層重量は $398 \mathrm{kN}$ となった。 なお，この 1 次固有周期は, 後述する強度指標 $\mathrm{C}$ の值が現実的な値 となる範囲で，3 層建物の初期周期として現実的な值となるように 定めた。直交壁付き柱からなるモテルの各層の初期哃性, 重量は壁 なし柱からなるモデルと同一とした。

\section{4 加力概要}

加力にはパンタグラフにより上部スタブの平行が保持される逆対 称加力装置を用いた。擬似動的加力における数值積分法は中央差分 法とした（ただし, 初期の数ステップは線形加速度法)。時間の縮尺 は 1 とし，積分時間間隔は $0.01 \mathrm{~s}$ とした。実験システムおよび加力 の手順は基本的に既往の実験 ${ }^{12)}$ と同様であるが, 解析モデルを 1 質 点系から 3 質点系にしたこと, 軸力を変動軸力から一定軸力にした こと等の変更を加えた。応答計算における減衰は初期剛性比例型と し，減衰定数を $1 \%$ とし。ここで，前述の実大モデルの応答計算 で算出された変形の $1 / 2$ を目標値として試験体を変形させ, 計測さ れた水平力を相似則により 4 倍して応答計算することを繰り返して 行った。なお，ひび割れ観察のため加力を停止することは行わず， 一定の時間間隔で継続加力した。 


\section{5 対象建物の Is 值}

実建物の 1 層の Is 值を第 2 次診断により求めた。柱の強度は, 表 1 に示したせん断強度 $V_{s}$ を相似則に従って 4 倍とした (軸力比 $=0.2$ )。 形状指標 $\mathrm{S}_{\mathrm{D}}$ と経年指標 $\mathrm{T}$ は 1.0 とした。壁なし柱試験体について勒 性指標 $\mathrm{F}$ を求めると, 柱は「せん断柱」と判定され， F=1.0であっ た。強度指標 C は 0.49 であり, 結果として Is 值は 0.49 となった。 なお, 強度指標を求める際の建物重量には 2.3 節で前述した実大モ デルの重量を使用した。この Is=0.49 は，既存の旧基準建物に対す る平均的な值であると考えることができる ${ }^{13) 。 ~}$

\section{6 入力地瑟動}

入力地震動として, 神戸海洋気象台 NS（JMA，1995 年兵庫県南 部地震), 東北大学 NS (TOH, 1978 年宮城県沖地震), 八戸市役所 $\mathrm{N} 254 \mathrm{E} （ \mathrm{HCO}, 1994$ 年三陸はるか沖地震）の3つを，入力レベルを 変更して用いた。入カレベルは, 最大耐力後の荷重低下を考慮した 予備解析により以下の基準で求めた。JMA と TOH に対しては, 壁 なし柱は崩壊するが，直交壁付き柱は崩壊しないレベルのうち最小 のものとした。HCOについては, 複数回の地震動を入力する意図か ら，壁なし柱と直交壁付き柱が共に崩壊しないレベルのうち最大の ものとした。なお，予備解析における復元力モデルは，壁なし柱に 対しては文献 3)のC13, 直交壁付き柱に対しては同 $\mathrm{C} 13 \mathrm{~W} 60$ の実験 結果を参考にして定めた。入力地震動の最大速度と最大加速度を表 3 に, 加速度時刻歴を図 4 にそれぞれ示す。地震動の継続時間は 20 秒とした。

表 3 入力地震動

\begin{tabular}{|l|c|c|c|}
\hline \multicolumn{1}{|c|}{ 名称 } & 略称 & 最大速度 $(\mathrm{cm} / \mathrm{s})$ & 最大加速度 $\left(\mathrm{cm} / \mathrm{s}^{2}\right)$ \\
\hline 神戸海洋気象台 NS & JMA & 60 & 594 \\
\hline 東北大学 NS & TOH & 70 & 434 \\
\hline 八戸市役所 N254E & HCO & 40 & 438 \\
\hline
\end{tabular}

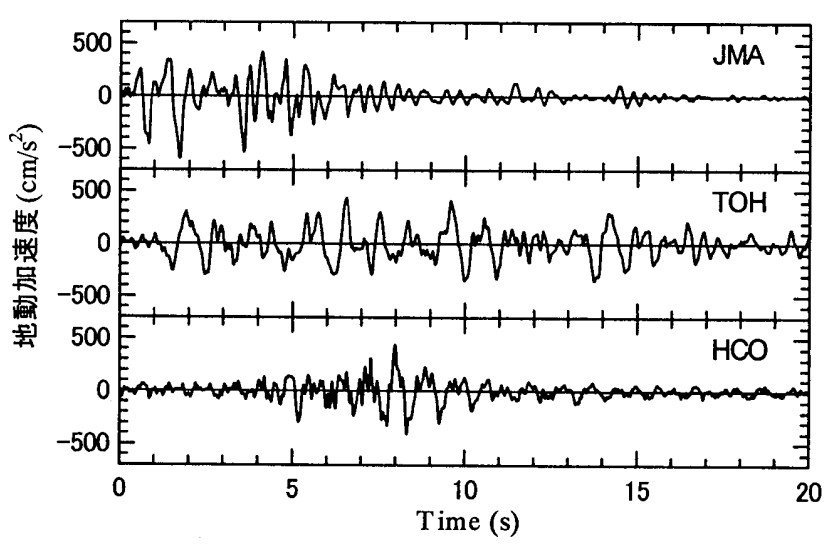

图 4 入力地震動の加速度時刻歴

\section{3. 実験結果}

\section{1 破圜過程}

実験の結果, 全ての試験体がせん断破壊し, 最終的に軸力保持能 力を䩚失して崩壊した。全ての試験体で, それまで安定して保持し ていた軸力を保持できなくなる点が存在したため, その直前の点を 軸力保持限界とした。また, 軸力保持限界に至るまでに経験した最 大の水平変形を「崩壊変形」と定義した。なお,これらの定義は筆
者らが過去に行った静的実験と同じである ${ }^{2), 3) 。 ~}$

C13W60-H のみは, 1 回の地震入力で軸力保持能力を品失しなか ったため, 一旦水平力, 軸力をゼロの状態にした後, 再び軸力を載 荷して, 同一の地震動を入力して 2 回目の加力を行った。ここで, 2 回目加力開始時の各層初期剛性は, 損賃を考慮して 1 回目加力の 1/10 とした。このとき 2,3 層の用性も誤って $1 / 10$ に変更しており, 1 回目加力と同じ振動体であるとはいえないため, 本論では 2 回目 加力の結果は復元力特性および崩壊変形の検討に対する使用のみに 止める。

1 層の水平変形時刻歴と水平力-水平変形関係を図 5 に示す。ここ で, 水平変形は柱内法高さで除した部材角で示す。水平力は試験体 相当の值を示す。実験結果一覧を表 4 に示す。C13W60-H のみは絽 り返しの最中に崩壊したため, 崩壊変形（3.28\%）は軸力保持限界 時の変形（3.0\%）とは異なる。なお，ひび割れ発生状況は実験時に 撮影したビデオにより確認したため比較的大きなひび割れの観察に 限定されており，初期の細かいひび割れは不明である。

実験の結果, C13W60-J と C13W60-T ではせん断ひび割れ発生と 同時に水平力が急激に低下するせん断ひび割れ破壊が生じた。また, 他の 4 体では最初のせん断ひび割れ発生後にもやや水平力が上昇し たものの, 間もなくして水平力が急激に低下した。C13-J とC13W60-J について軸力保持限界時の破壊状況を写真 1 に示す。水平力の急激 な低下以降は写真で大きく開いているひび割れが主要な破壊であっ た。壁なし柱試験体について，せん断ひび割れ強度とトラス・アー チ機構によるせん断強度の計算值を表 1 に示すが, 前者が後者より も大きい場合にはせん断ひび割れ破壊を起こす傾向があるとされて おり ${ }^{14)}$ ，本試験体はこれに該当するといえる。全ての試験体で，上 記の水平力の急激な低下が生じたときにせん断補強筋の引張降伏が 生じた。この現象が生じた直前のステップを「せん断破壊時」とし, 図 5 中にメで記し，そのときの水平変形を表 4 に示す。直交壁付き 柱ではせん断破壊時と最大水平力時が一致し, 壁なし柱では前者は 後者より少し後であった。

\section{表 4 実験結果一筫}

\begin{tabular}{|c|c|c|c|c|c|}
\hline 試験体名 & $\begin{array}{c}\text { 最大 } \\
\text { 水平力 } \\
(\mathrm{kN})\end{array}$ & $\begin{array}{c}\text { 最大水平 } \\
\text { 力時変形 } \\
(\%)\end{array}$ & $\begin{array}{c}\text { せん断破 } \\
\text { 壊時変形 } \\
(\%)\end{array}$ & $\begin{array}{l}\text { 直交壁南面・ } \\
\text { 北面ひび割れ } \\
\text { 発生時変形(\%) }\end{array}$ & $\begin{array}{c}\text { 崩壊変形 } \\
(\%)\end{array}$ \\
\hline C13-J & 191 & 0.66 & 0.81 & \multirow{3}{*}{-} & 1.66 \\
\hline $\mathrm{C} 13-\mathrm{T}$ & 201 & 0.68 & 1.10 & & 2.48 \\
\hline $\mathrm{C} 13-\mathrm{H}$ & 212 & 0.95 & 0.96 & & 2.87 \\
\hline C13W60-J & 224 [1.17] & 0.73 & \multirow{3}{*}{ 同左 } & 南 1.28 , 北 2.05 & 2.80 [1.69] \\
\hline C13W60-T & 211 [1.05] & 0.65 & & 南 2.48 , 北 2.71 & 2.71 [1.09] \\
\hline C13W60-H & 219 [1.03] & 0.77 & & 南 2.70 , 北 3.00 & $3.28[1.14]$ \\
\hline
\end{tabular}

変形は部材角。 [ ]内は, 同一地震動の場合の壁なし柱に対する比率。

\section{2 直交壁の効果}

既往の研究 ${ }^{3)}$ では直交壁により構造性能が上昇するとされており, これは本実験でも同様であった。特に HCO の地震動を用いた場合, 壁がない C13-H が 1 回目の加力で崩壊したのに対して, 直交壁が付 いた C13W60-H では 1 回目の加力では崩壊を免れ, 直交壁の効果が 顕著に表れた。 


\subsection{1 最大水平力}

最大水平力は, 壁なし柱で 191〜 $212 \mathrm{kN}$, 直交壁付き柱で 211 224kN で あった。各地震動ごとに，壁なし柱の 最大水平力に対する直交壁付き柱の最 大水平力の比を表 4 に示す。その値は 1.03 から 1.17 であり, 平均值は 1.08 であった。直交壁により最大水平力が 上昇した。なお，静的実験の文献 3)に おける $\mathrm{C} 13$ と $\mathrm{C} 13 \mathrm{~W} 60$ ではこの值は 1.08 であり,本実験と同程度であった。

\subsection{2 崩噇変形}

崩壊変形を図 6 に示す。壁なし柱の 崩壊変形は $1.66 \sim 2.87 \%$ であり, 平均 值は $2.34 \%$, 変動係数は 0.26 であった。 直交壁付き柱の崩壊変形は 2.71 $3.28 \%$ であり, 平均值は $2.93 \%$, 変動係 数は 0.10 であった。壁なし柱では地震 動（載荷履歴）の違いによりややバラ ツキが大きかった。

各地震動ごとに壁なし柱の崩壊変形 に対する直交壁付き柱の崩壊変形の比 を表 4 に示す。その值は 1.09 から 1.69 であり，平均値は 1.31 であった。直交 壁により崩壊変形が上昇した。なお, 静的実験における試験体 C13 では崩壊 変形 $1.28 \%, \mathrm{C} 13 \mathrm{~W} 60$ では同 5.23\%で あり，直交壁付き柱/壁なし柱の值は 4.09 であった 3)。これは本実験よりも 相当大きい值であるが, この理由は不 明であり，今後の課題である。また， 前述の予備解析では全ての直交壁付き 柱が崩壊しなかったのに対して，実験 では 2 体が崩壊したのであるが，直交 壁付き柱の崩壊変形が予備解析で考慮 した静的実験結果よりも小さく, 予想 よりも直交壁の効果が小さかったため である。

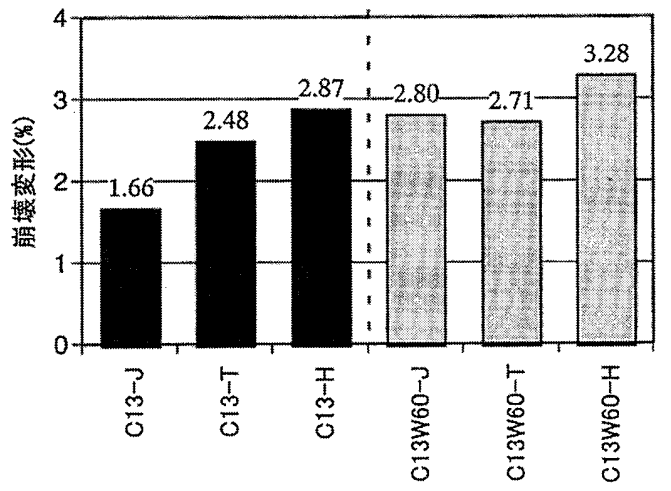

図 6 崩塹变形
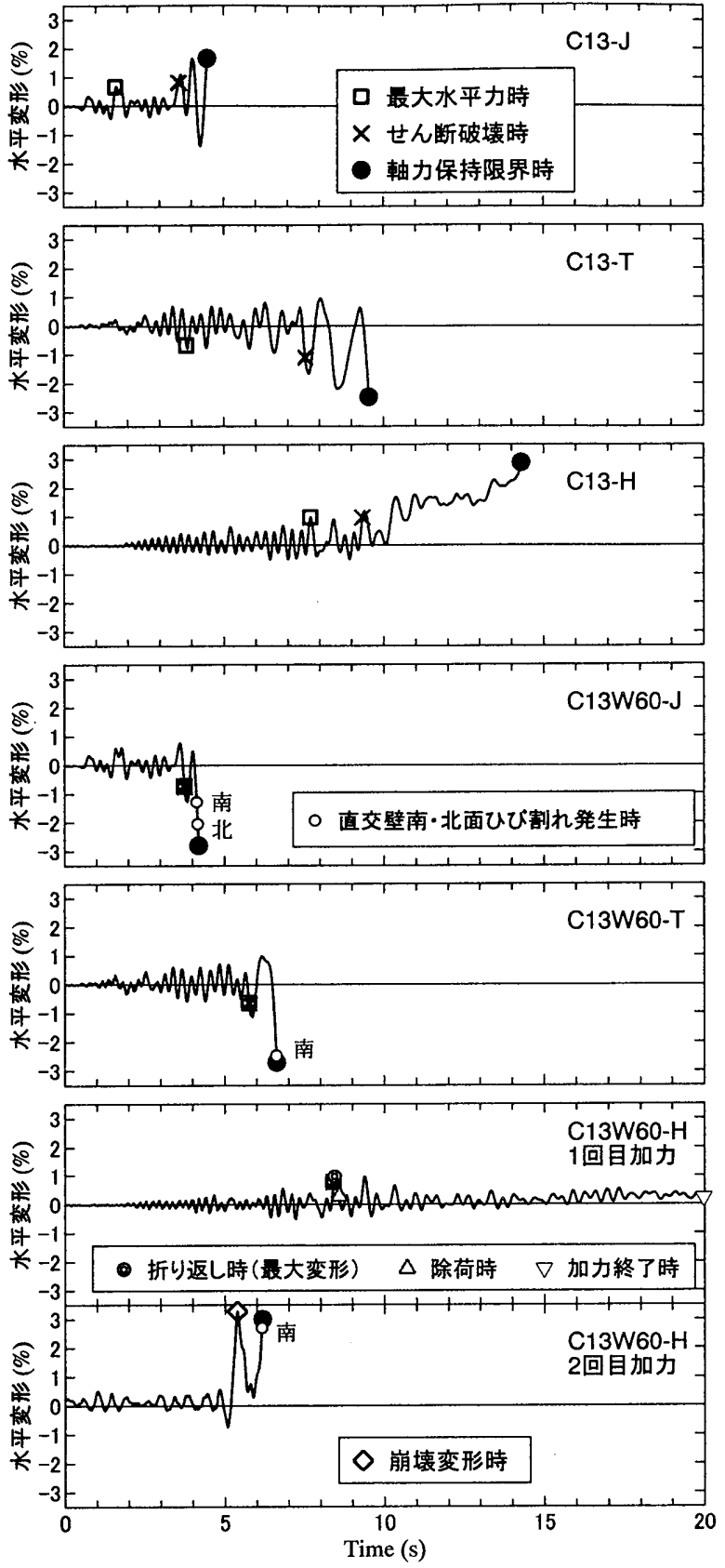

（a）水平变形時刻歴

図 5 実硂結果
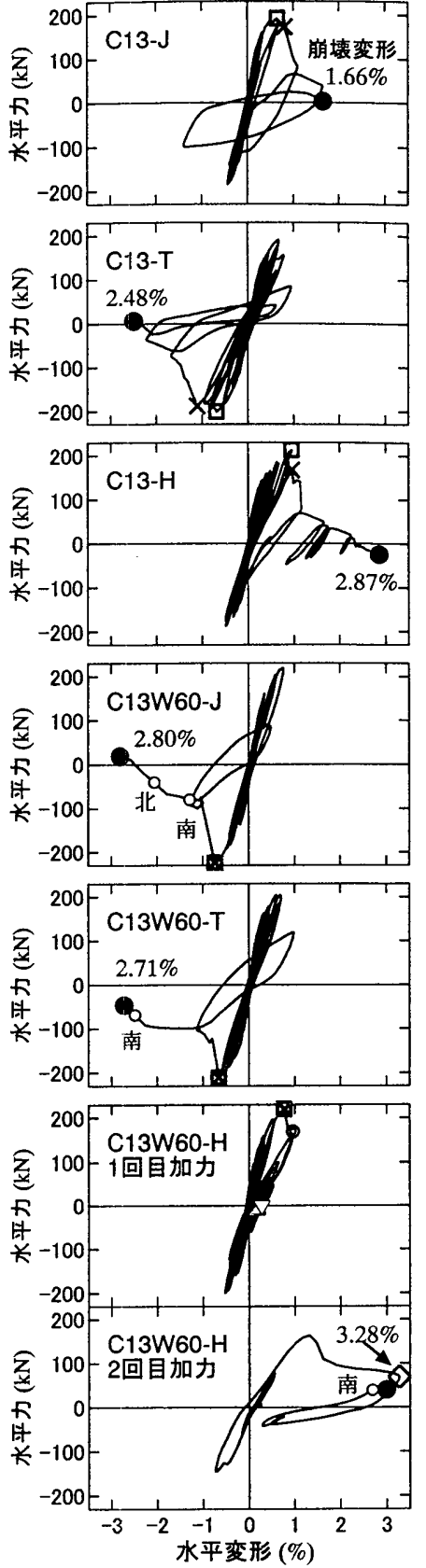

（b）水平力-水平変形関係

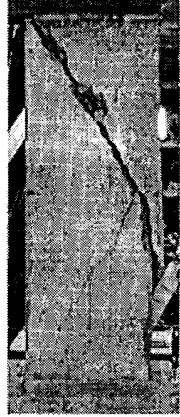

(南面)

(a) $\mathrm{C} 13-\mathrm{J}$
点線内：直交壁南面 柱のせん断ひび割れと連続

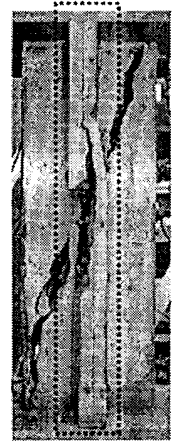

(南面)

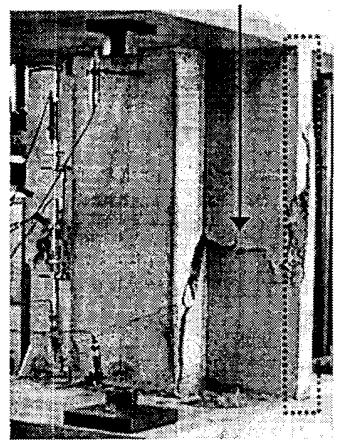

(南西面)

写真 1 破壞状況（軸力保持限界） 


\subsection{3直交壁の破壊過程}

直交壁付き試験体について, 直交壁の南面および北面において縦 方向にひび割れが生じた点を図 5 に○で示し，そのときの水平変形 を表 4 に示す。ここで南面・北面とは，写真 1(b)に点線で示すよう に，南北方向に2つある直交壁それぞれの，柱とは接しない面を示 す。このひび割れは，写真 1(b)の右の写真に示すように，柱のせん 断ひび割れと連続していた。なお，C13W60-T と C13W60-H の北面 ひび割れは崩壊と同時に生じた。図 5(a)より，南面または北面にひ び割れが生じた後, 間もなくして崩壊したことがわかる。文献 3)の C13W60 と同様に，直交壁の南面または北面にひび割れが生じると 壁の軸力保持能力が低下してそれまで壁が負担していた軸力が柱に 移動し，間もなくして崩壊に至ったと考えられる。表 4 より，3 体 ともに北面ひび割れ時変形は同一地震動の壁なし柱の崩壊変形より も大きく，これが直交壁により崩壊変形が上昇した理由であるとい える。

\section{3 崩壊時の地動加速度の大きさ}

C13-H では, 地震動の強震部を過ぎた後に徐々に水平変形が增加 して行き，地動加速度が小さい領域で崩壊した。地動加速度が小さ くとも, 応答変形が徐々に増加して崩壊に至ることがあるといえる。 一方, 他の試験体は強震部で崩壊したが, 設定した地震動レベルが もう少し小さかったならば，小加速度領域まで崩壊しない例が增え た可能性がある。

\section{4 地軣動レベルと崩壇}

C13W60-H を除いて, 最大速度 40〜70(cm/s)[最大加速度 $400 \sim$ $600\left(\mathrm{~cm} / \mathrm{s}^{2}\right)$ 程度]の地震動で崩壊した。本論で対象とした Is $=0.49$ 程度 の建物では，このようなレベルの地震動で崩壊に至るといえる。こ こで, 壁なし柱の崩壊変形を既往の推定式 2)により求めると下限值 である $1.5 \%$ となり, せん断柱の中でも最も変形能力に乏しい柱であ ると評価された。実験結果も 3.2.2 項に示した通り小さな值であった。

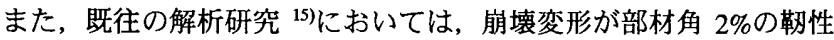
能に乏しいせん断柱からなる 3 首建物に対して, 最大速度 $50(\mathrm{~cm} / \mathrm{s})$ の地震動に対して崩壊を防ぐためには 0.5 程度の Is 值が必要であっ たという結果が得られているが，本実験の結果は概ねそれと一致し ているといえる。一方，本試験体より変形能力に富むせん断柱であ れば，同じ Is=0.49 の建物でも崩壊を免れることも考えられる ${ }^{15) 。}$

\section{5 水平変形の片寄りについて}

水平変形の片寄りの性状について図 5 により検討する。C13-J で は，崩壊変形に対する崩壊した方向と逆方向の最大変形の比は $84 \%$ であり, 水平変形の大きな片寄りは生じなかった。一方, 他の 5 つ の試験体におけるこの比は.17〜38\%であり, 水平変形が片方向（崩 壊する方向）に寄る傾向があった。本実験のような大きく荷重低下 する柱では水平変形が片寄る場合が多いといえる。

ところで, 過去の静的実験において, 繰り返し載荷の最中に水平 変形が小さい時点で崩壊した例が多く見られるが 1) 3)，本実験では このような現象は生じず，すべて崩壊したときの変形が最大変形に 等しいか，それに近いものであった。この理由として，静的実験で は正負同じ変形を生じさせて繰り返し載荷を行ったのに対して，本 実験では変形が片寄りであったことが考えられる。ただし，擬似動 的実験においても上記の静的実験のような現象が生じる可能性があ るので，今後更なる実験を行って確認する必要がある。

\section{6 残留变形に関する考案}

地震被害調查の際に観察できるのは地震終了後の残留変形である。 そのため,これと地震時の最大変形とを対応させることができれば, 建物の損傷評価に役立てることができるが，このような検討は既往 の振動台実験 4) 6)では行われていない。そこで, 1 回の地震入力で 崩壊を免れた C13W60-Hについて残留変形を検討する。ここで，水 平変形が増加から隇少に転じる点を「折り返し時」，そこから除荷さ れて水平力がゼロになった点を「除荷時」と定義する。図 5 中に, 折り返し時が最大変形である点（○：水平変形 $\mathrm{R}=0.85 \%)$ およびそ こからの除荷時（ $\triangle: \mathrm{R}=0.28 \%)$ を示す。併せて地震終了時（ $\nabla:$

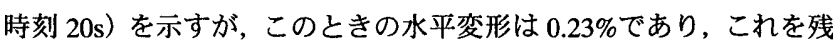
留変形とすると, 最大変形からの除荷時変形と概ね同じであること がわかる。これは，せん断破壊が生じた方向に応答変形がドリフト していく傾向によるものと考えられる。ただし，あくまでもひとつ の試験体における結果であるため，今後更なる検討が必要である。

ところで, 折り返し時変形と除荷時変形の関係については, 過去

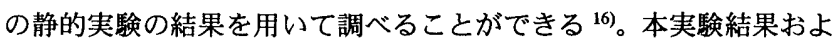
び筆者らが過去に行ったせん断破壊型 RC 柱の実験結果 ${ }^{2), 3)}$ について, 折り返し時水平変形と除荷時水平変形の関係を, 壁なし柱と直交壁 付き柱に分けて図 7 に示す。試験体数は，壁なし柱が計 15 体, 直交 壁付き柱が計 7 体である。これらのパラメー夕範囲は, $\mathrm{h}_{0} / \mathrm{D}=2 \sim 4$, 主筋比 $\mathrm{p}_{\mathrm{g}}=1.69 \sim 2.65 \%$, せ九断補強筋比 $\mathrm{p}_{\mathrm{w}}=0.11 \sim 0.21 \%$, 軸力比 $=0.18 \sim 0.35$, 直交壁の壁厚 $=60 \mathrm{~mm}$ と $90 \mathrm{~mm}$ である。なお, 対象とす る折り返し時変形は, 最大水平力時を超えた後で, かつ最大水平力 時変形以上のものとした。図より, 折り返し時水平変形が大きいほ ぞ除荷時水平変形が大きくなる傾向があり，両者には概ね対応関係 がある。また擬似動的実験と静的実験には明確な違いは見られない ことがわかる。ここで, データ数が多い壁なし柱について, 仮に最 も単純に線形近似した直線を図 7(a)に破線で示す。除荷時変形は折 り返し時変形の $70 \%$ 程度であるといえる。ただし, 折り返し時変形

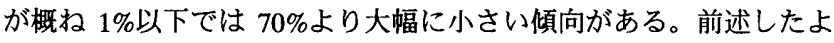
うに最大変形からの除荷時変形と残留変形が概ね同じであれば，折 り返し時変形を地震時の最大変形と考えることにより,残留変形 $($ ○ 除荷時変形）から最大変形を推定できる可能性があるといえる（注 2)。なお，解析による既往の研究 ${ }^{15)}$ では，せん断破壊型柱の残留変 形は最大変形の $1 / 8$ 以下であるという結果が示されており，本検討 と様相が異なったが, 解析の復元力モデルの設定が結果に大きく影 響するため,これについては今後の検討課題である。

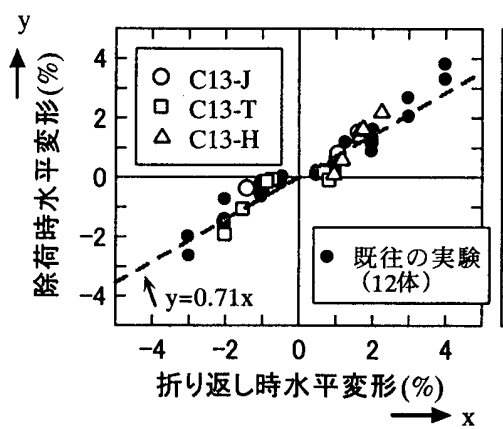

（a）壁なし柱

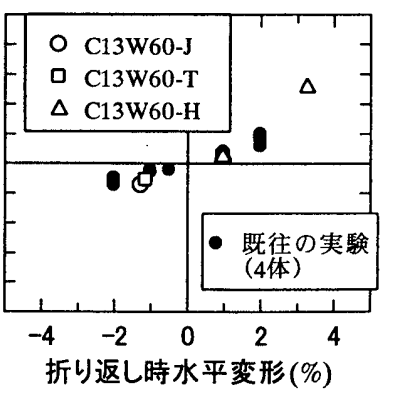

（b）直交壁付き柱
図 7 折り返し時水平变形と除荷時水平変形の関係 


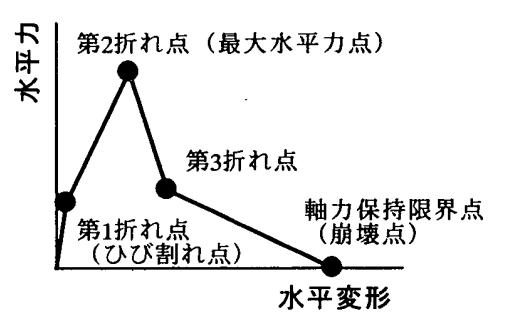

図 8 復元カスケルトンの概要

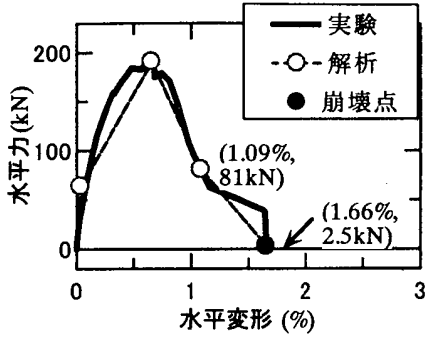

(a) $C 13-\mathrm{J}$

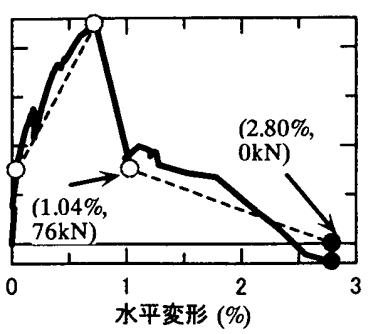

(b) $\mathrm{C} 13 \mathrm{w} 60-\mathrm{J}$

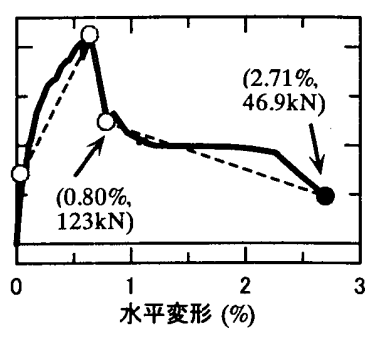

(c) $\mathrm{C13W60-T}$

図 9 復元カスケルトンの比较（実験結果と解析モデ）

\section{4. 解析による実験結果の再現}

擬似動的実験の結果を地震応答解析により再現することは, 解析 の信頼性を検証するうえで重要である。従来このような検討はせん 断破壊型柱ではほとんど行われておらず7，特に崩壊までを対象と したものは無い。そこで, 地震応答解析による実験結果の再現を試 み, 適合性を検討した。

\section{1 解析モデ}

解析モデはせん断多質点系で, 各層の初期剛性と重量は実験時 と同じとし (2.3 節参照)， 1 層を弾塑性， 2,3 首を弾性とした。減 衰は初期剛性比例型で, 減衰定数を $1 \%$ とた。

\section{2 復元カモデル}

1 層の復元力モテルは, 文献 15)においてせん断破壊型柱に対して 用いたものとした。復元力スケルトンの概要を図 8 に示す。復元力 スケルトンは各試験体について以下の(1) (4)で定めた。これは, 実 験と解析の対応を見る第一段階として, 各試験体で実験結果に最も 近いものとなるように定めたものである。対象の試験体は 1 回の地 震入力で崩壊した 5 体とした。

(1)第 1 折れ点時の水平力は, 第 2 折れ点時水平力の $1 / 3$ とした。

(2)第 2 折れ点時の水平力と水平変形は実験結果と同じとした (表 4)。

(3)第 3 折れ点時の水平力と水平変形は各実験結果と適合するように 適宜定めた。

(4)軸力保持限界点の変形（崩壊変形）は実験結果と同じとした（表 4)。そのときの水平力も実験結果と同じとしたが, 実験結果が負 になる場合にはゼロとした。

例として C13-J, C13W60-J, C13W60-T について, 実験結果と解 析モデルの復元力スケルトンの比較を図 9 に示す。図中の括弧内は 第 3 折れ点と崩壊点の水平変形と水平力を示す。水平力は試験体相 当の值を示す。

繰り返しの履歴ルールについても, 文献 15)と同じとした。これ は同文献において既往のせん断破壊型柱の実験結果と良く一致する 様に定めたものであり, 本実験結果にも同様に適用できると考える。

\section{3 解析䊅果}

各モデルに，2.6節で示した地震動を入力して解析を行った。

\subsection{1 適合性が良い例}

C13W60-J に対する 1 層の水平変形時刻歴, 水平力時刻歴, 水平 力-水平変形関係を図 10(a),(b),(c)にそれぞれ示す。図 10(a)より, 水 平変形は崩壊時までおおむね実験と解析が一致したことがわかる。 特に, 崩壊の時刻がほほ一致していることから, 崩壊までを解析で 再現するという本解析の目的を達しているといえる。ただし, 水平 力は時刻 4 秒付近の崩壊に近い範囲で対応が悪かった（図 10(b))。
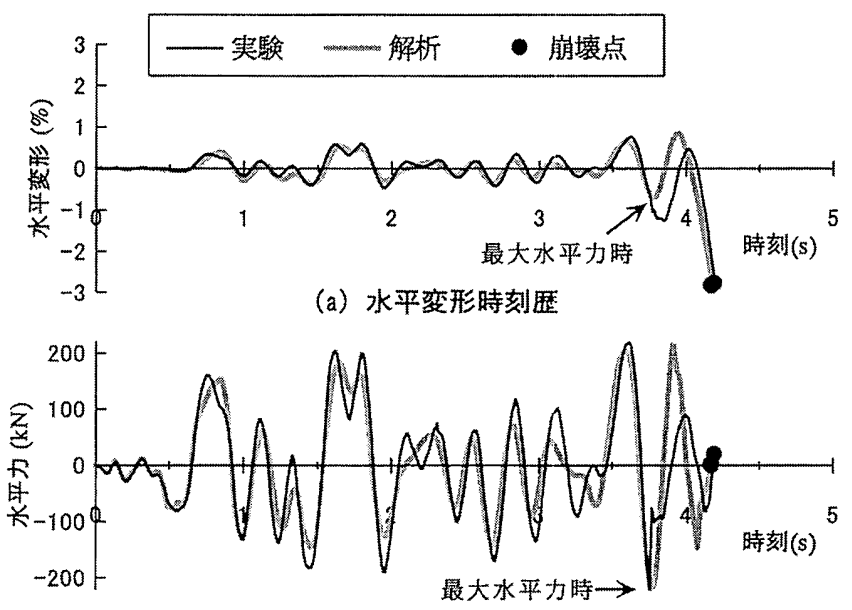

(b) 水平力時刻歴

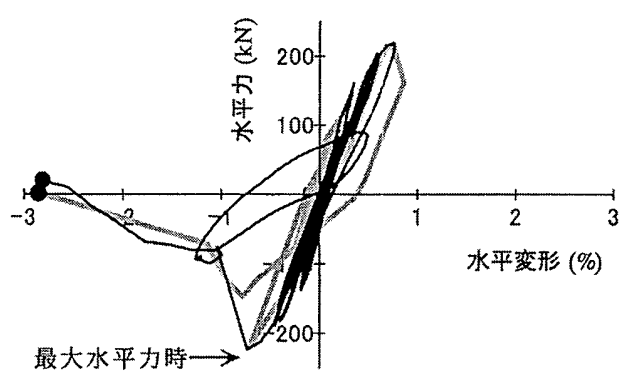

(c) 水平力-水平変形関係

図 10 実験と解析の比較 $(\mathrm{C} 13$ W60-J)

これは図 10(c)に示すように, 最大水平力後, 実験では耐力が低下し て変形がやや大きくなったのに対して, 解析では直ちに除荷に入り, 反対方向（正側）で耐力がやや低下した後に崩壊に至った, という 違いに起因する。

\subsection{2 適合性が覀い例}

C13-J に対する 1 層の水平変形時刻歴と水平力-水平変形関係を図 11(a),(b)にそれぞれ示す。図 11(a)より, 崩壊するという現象は再現 できたが，崩壊時刻が実験では約 4.5 秒であったのに対して解析で は約 1.7 秒であり, 対応が悪いことがわかる。図 11(a),(b)より, 最大 水平力後, 実験では除荷領域に入って応答がしばらく継続したのに 対して, 解析では直ちに荷重が低下して崩壊に至ったことがわかる。 この試験体では解析の変形が実験より大きめに生じたといえる。

一方, C13-T, C13-H, C13W60-Tでは, 実験では崩壊したのに対 して解析では最大変形が最大水平力時変形のそれぞれ $105 \%, 85 \%$, 105\%にとどまり，崩壊には至らなかった。一例として C13W60-Tに 
対する 1 層の水平変形時刻歴と水平力-水平変形関係を図 $12(\mathrm{a}),(\mathrm{b})$ に それぞれ示す。図12(a)より, 解析では水平変形が実験よりも小さな 值となったことがわかる。図 9(c)より, 荷重が低下する以前のエネ ルギー吸収能力は解析のほうが小さいが（注 3), それにも関わらず 水平変形が小さくなった理由は不明である。

以上より, C13W60-J を除く 4 体では実験と解析の対応が悪く, 崩壊までの再現は困難であった。曲げ破壊型の荷重が低下しない柱 に対しては解析により実験結果をよく再現できることが知られてい るがたとえば 17), 荷重が大きく低下する柱に対しては復元力スケルトン を実験結果に適合させた解析を行っても再現は困難であるといえる。

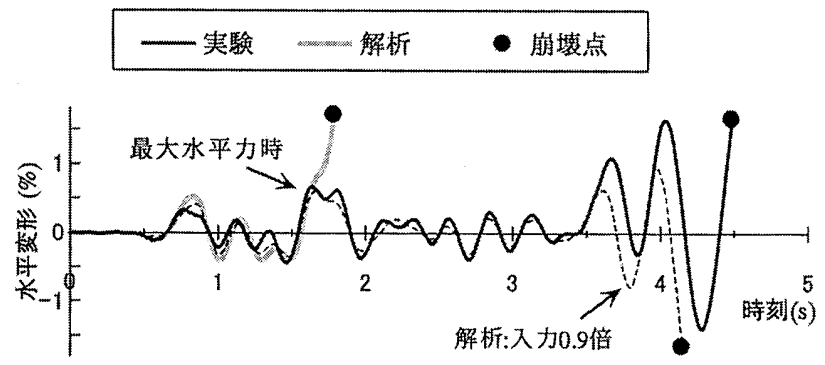

(a) 水平变形時刻歴

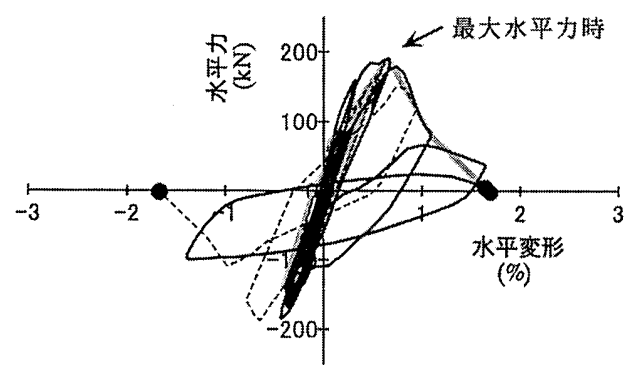

（b）水平力-水平变形関係

図 11 実験と解析の比較 (C13-J)

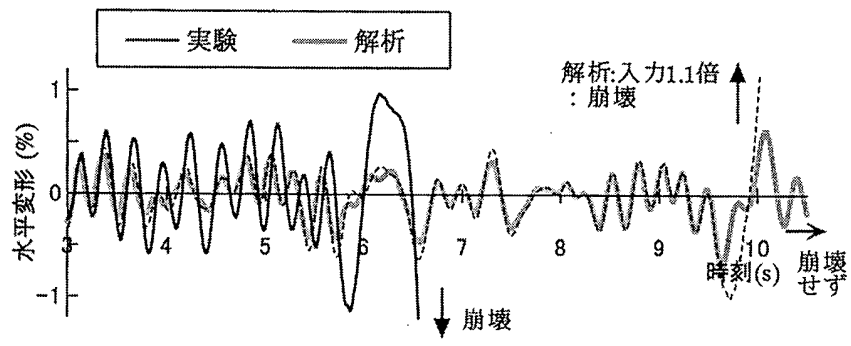

(a) 水平変形時刻歴

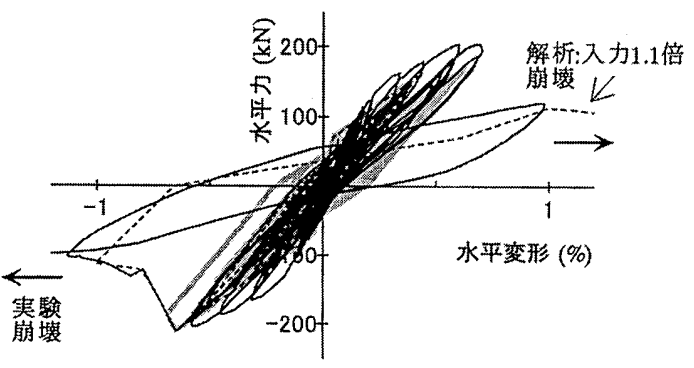

（b）水平力-水平変形関係

図 12 実検と解析の比較 (C13W60-T)

\subsection{3 適合性が悪い例に対する终正の試み}

前項で実験と解析の対応が悪かった理由として, 以下が考えられ る。すなわち, 本実験で用いた柱は崩壊変形が小さく, 最大水平力 後急激に荷重が低下して崩壊に至るものであったため, 応答が地震 動の大きさに敏感に影響され, 解析で変形が大きめに生じたり，あ るいは小さめに生じて崩壊しないことが起きたりしたと考えられる。 そこで, 仮に地震動の入カレベルを変化させた解析を試みた。

解析での応答変形が大きかった C13-J に対して入カレベルを 0.9 倍して解析した結果を図 11 中に点線で示す。この場合崩壊に近い範 囲では対応が悪いものの, 解析結果は実験に近づいた。

解析での応答変形が小さかった C13W60-Tに対して入力レベルを 1.1 倍して解析した結果を図 12 中に点線で示す。この場合は変形時 刻歴の対応は悪いものの, 崩壊は生じた。これは C13-T でも同様で あった。C13-Hに対しては入力レベルを 1.3 倍した場合に崩壊した。

以上より, 解析結果は地震動レベルに非常に敏感であり, 本実験 で対象としたような崩壊変形が小さく, 最大水平力後の荷重低下が 急激な柱では，解析で実現象を正確に再現することは困難であると いえる。ただし, 解析手法の発展によって実現象を解析で再現可能 となることも考えられるため，今後検討する余地が残されていると いえる。いずれにしても現状では，このような柱に対して崩壊性状 を検討するためには擬似動的実験を実施することが有効であるとい える。なお，本実験よりも崩壊変形が大きく荷重低下が緩やかな柱 の場合には, 実験と解析がより一致する可能性があると考えている。

\section{5. まとめ}

旧基準 3 首 $\mathrm{RC}$ 建物を対象として，サブストラクチャ擬似動的実 験によりせん断柱のなかでも特に変形能力に乏しい柱の崩壊性状 を検討した。実験対象は 1 層の柱とし，その層の Is 值を 0.49 とし た。入力地震動は 3 種類とした。得られた知見を以下に示す。

1) 最大速度 $40 \sim 70(\mathrm{~cm} / \mathrm{s})\left[\right.$ 最大加速度 $\left.400 \sim 600\left(\mathrm{~cm} / \mathrm{s}^{2}\right)\right]$ の地震動で崩 壊した。Is=0.49 程度で変形能力の乏しい柱であれば, この程度 の地震動で崩壊するといえる。

2) 地震動 HCO を入力した場合には, 直交壁が付くことにより崩壊 を免れた。また，地震動ごとに比較すると，直交壁が付くことに より最大水平力が $1.03 \sim 1.17$ 倍, 崩壊変形が 1.09〜1.69 倍となつ た。なお，過去の静的実験では破壊過程は本実験とほぼ同様で， 直交壁が付くことにより最大水平力が 1.08 倍, 崩壊変形が 4.09 倍となり, 後者は本実験よりも相当大きかった。総じて直交壁に より耐震性能が上昇するといえる。

3) 1 つの試験体を除く 5 つの試験体で, 水平変形が片方向に寄り, 片押し的な応答であった。荷重が大きく低下する柱が崩壊に至 る場合には応答変形が片方向に寄る場合が多いといえる。

4) ひとつの試験体は地震動の強震部を過ぎた後, 地動加速度が小さ い時点で崩壊した。柱が損傷して崩壊に近づいている場合にはこ のようなことが起こり得るといえる。

5) 1 回の地震入力で崩壊しなかった試験体では, 残留水平変形と最 大変形からの除荷時水平変形は概ね同じであった。また, 折り返 し時水平変形と除荷時水平変形の関係を過去の静的実験結果を 含めて調べた結果，両者には対応関係があった。残留変形から最 大変形を推定できる可能性があるといえる。 
6) 1 回の地震入力で崩壊した 5 体について, 復元カスケルトンを実 験結果に合わせたモデルを用いた地震応答解析によって実験結 果の再現を試みた。その結果, 1 体に対しては崩壊までの応答を 概ね再現できたが，他の 4 体は崩壊までは再現できなかった。荷 重が大きく低下する柱に対しては復元カスケルトンを実験結果 に適合させた解析を行っても再現は困難であるといえる(付録)。 そのため, せん断破壊型柱の崩壊性状を検討するうえで擬似動的 実験は有効である。

\section{謝辞}

本研究は, 文部科学省科学研究費補助金（課題番号 15760430）の 一環として行ったものである。ここに記して謝意を表する。

\section{参考文献}

1) Hassane Ousalem, Toshimi Kabeyasawa, Akira Tasai and Junichi Iwamoto: Effect of Hysteretic Reversals on Lateral and Axial Capacities of Reinforced Concrete Columns, Proceedings of the Japan Concrete Institute, Vol.25, No.2, pp.367-372, 2003.7

2) 芳村 学, 高稻宜和 : 崩壊変形を含さ鉄筋コンクリート柱の荷重低下域における挙 動の定式化，日本建築学会構造系論文集, No.587, pp.163-171, 2005.1

3) 金 紅日，中村孝也，芳村 学 : せん断破壊型 $\mathrm{RC}$ 柱の崩壊に対する直交壁の影響, コンクリート工学年次論文集, 第 27 巻, 第2 号, pp.193-198, 2005.6

4) Namihiko Inoue, Eiichi Inai, Akira Wada, Hiroshi Kuramoto, et al.: A Shaking Table Test of Reinforced Concrete Frames Designed under Old Seismic Regulations in Japan, Proceedings of the12th WCEE, CD-ROM, Paper No.1783, 2000.1

5) K. J. Elwood and J. P. Moehle: Shake Table Tests on the Gravity Load Collapse of Reinforced Concrete Frames, Proceedings of The Third US-Japan Workshop on Performance-Based Earthquake Engineering Methodology, pp.407-420, 2001.8

6) 金 裕錫, 壁谷澤寿海, 加藤 敦, 小川信行, 五十嵐俊一:鉄筋コンクリート偏心ピロ テイ壁フレーム構造の振動破壊実験（その1）鉄筋コンクリート造試験体の応答性 状, 第 11 回日本地震工学シンポジウム, pp.1421-1426, 2002.11

7) 池田尚治, 山口隆裕, 粕澤哲史 : 地震動による鉄筋コンクリート柱の挙動と供用 性能の評価，コンクリート工学年次論文報告集，第 12 巻，第 2 号, pp.119-124, 1990.6

8) 日本建築防災協会 : 既存鉄筋コンクリート造建築物の耐震診断基準 同解説, 2001.10

9) 日本建築学会:鉄筋コンクリート造建物の勒性保証型耐震設計指針・同解説, 1997.7 10)日本建築学会 : 鉄筋コンクリート造建物の終局強度型耐震設計指針・同解説, 1990.11

11)日本建築学会 : 鉄筋コンクリート終局強度設計に関する資料, 1987.9

12)山崎真司, 見波 進, 見村博明ほか : 鈶直地震動による変動軸力が鋼柱の弾塑性水 平地震応答に及ぼす影響, 日本建築学会構造系論文集, No.529, pp.167-174, 2000.3 13)日本建築学会 : 1995 年兵庫県南部地震鉄筋コンクリート造建築物の被害調査報告 書第 II 編 学校建箱, 1997.3

14)高稻宜和, 芳村 学 : 鉄笳コンクリート柱の破壊モードの評価に関する一考察, 日 本建策学会構造系論文集, No.600, pp.139-146, 2006.2

15)上野裕美子，芳村 学，中村孝也：既存低層鉄筋コンクリート建物の Is 值と倒壊 の関係一診断基準における「せん断柱」からなる建物を対象として一，日本建築学 会構造系論文集，第 587 号，pp.197-204，2005.1

16)城戸将江, 江崎文也ほか : RC 柱曲げ降伏以後の経験部材角と残留変形角と の関係，コンクリート工学年次論文集，第 26 巻，第 2 号, pp.187-192，2004.7

17)岡田恒男, 関 松太郎 : 電算機ーアクチュエーターオンラインシステムによる鉄筋 コンクリート骨組の地震応答実験 その 2 オンライン応答実験 -1 , 日本建築学 会論文報告集，第279 号, pp.77-84，1979.5

注

注1) 古い建物の中には，けた行方向が極めて脆性的なせん断破壊型柱のみで 構成されているものが存在しており, 過去の地震においては, それらの 建物で層崩壊の被害が発生している。そのため本研究では，そのような
建物の崩壊性状を明らかにすることが優先課題であると考え, 1 種類の 脆性的な柱のみからなる場合を検討した。それに対して, 複数種の鈶直 部材からなる建物では, 脆性的な柱が軸力保持能力を张失しても, 梁が 十分に強ければ周辺の䩗性的な柱や耐震壁などに軸力が移動して直ち に崩壊には至らず，本研究で示した崩壊性状とは様相が異なると考えら れる。

注2) 崩壊間近では水平力が低下してゼロに近づいており, 折り返し時から除 荷時までに直ちに到達するためその間の変形量が少なく, 前者に対する 後者の変形の比は, 最大水平力直後のそれと比べると大きくなり，1 近づくものと考えられる。ここで，崩壊変形は柱の諸元によって大きく 異なるため（図 7(a)に示した計 15 体の試験体では 1.28〜20.6\%), 折り 返し時変形-除荷時変形関係と, 崩壊に近いか否かの関連を論じるために は，例えば図 7 の綐軸，横軸をそれぞれの試験体ごとに崩壊変形で除す るなどして, 折り返し時変形・除荷時変形を崩壊変形と関連づける必要

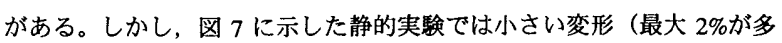
い）で繰り返した後, 崩壊するまで片方向に押し切ったものが多いため, 崩壊に近い笨围で除荷したデータが少ないのが現状である。そのため本 論では, 折り返し時変形・除何時変形と崩壊変形との関係の検討は行わ ず, 第一段階として単純に絶対的な変形量での比較を行った。今後, 新 たに擬似動的実験を行って崩壊に近い範囲で除荷が生じたり, あるいは 静的実験でも崩壊に近い範囲で綝り返しを行う等の実験データが增え たりすれば, 崩壊変形との関連を検討することができるようになると考 えている。

注3) 解析モデルでは原点と第 1 折れ点までは直線であるが, 実験では解析で 仮定した第 1 折れ点以前に剛性が低下するため，この䉓囲では解析の工 ネルギー吸収能力が実験よりも大きくなる（図 9)。ただし，解析結果に 及ぼす影響は，第 1 折れ点から第 2 折れ点までの範囲の方が大きいと考 えられ，ここでは解析のほうが小さいため, 総じて荷重が低下する以前 のエネルギー吸収能力は解析のほうが小さいとみなした。

付録 C13-Jに関する追加解析

第 4 章では, 復元力スケルトンの第 2 折れ点（図 8 参照）を実験結果の最 大水平力点と一致させた解析を行った。しかし, 図 9(a)に示した試験体 C13-J の実験結果に着目すると, 最大水平力の付近で水平力が緩やかに低下する領 域があり，上に尖った形状の解析モテルとは異なっている。そこで，付図 1 に示すように, 復元力スケルトンの第 2 折れ点と第 3 折れ点を実験結果に適 宜合わせて水平力が緩やかに低下する領域を持たせたモテルによる解析を行 った。この解析結果と実験の比較を, 1 層の水平変形時刻歴について付図 2 に示す。崩壊付近での適合性は悪いものの, 図 11(a)に示した解析結果 ( の 線）と比べると適合性がはるかに上がっている。このように復元力スケルト ンの設定方法によって解析の精度を改善する余地が残されているといえる。

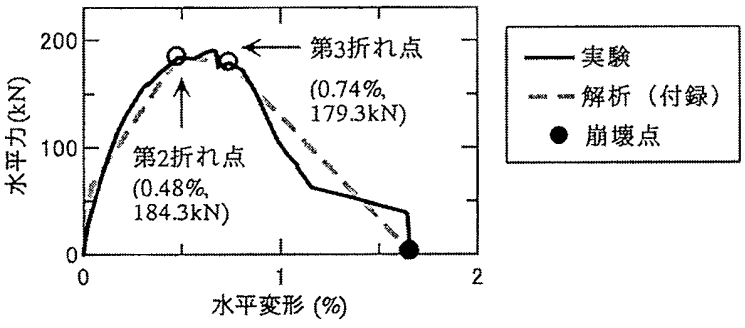

付図 1 復元カスケルトン（実験と解析の比較, (13-J)

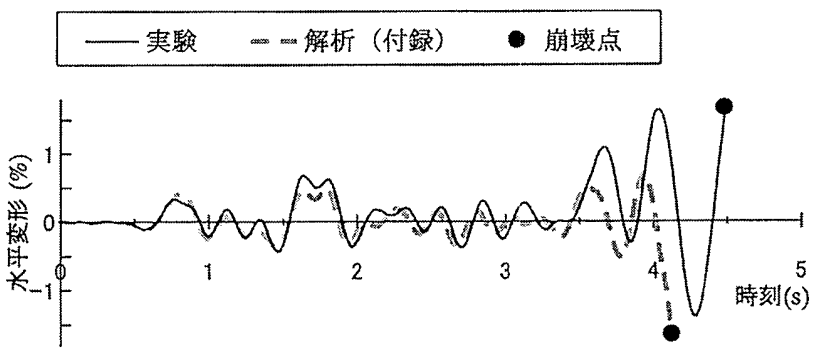

（2006年12月 10日原稿受理，2007年 5 月18日採用決定） 